\title{
REMOTE SENSING AND GIS APPROACHES TO A QUALITATIVE ASSESSMENT OF SOIL EROSION RISK IN SERANG WATERSHED, KULONPROGO, INDONESIA
}

\author{
N. Arif ${ }^{a, b}$, P. Danoedoro ${ }^{b}$, H. Hartono ${ }^{b}$ \\ ${ }^{a}$ Faculty of Science and Technology, Universitas Muhammadiyah Gorontalo, Indonesia \\ ${ }^{b}$ Faculty of Geography, Universitas Gadjah Mada, Yogyakarta, Indonesia
}

\section{Article Info:}

Received: 17 February 2017

in revised form: 06 May 2017

Accepted: 7 July 2017

Available Online: 30 October 2017

\section{Keywords:}

Remote sensing, Serang Watershed, soil erosion

\section{Corresponding Author:}

Nursida Arif

Faculty of Science and Technology, Universitas Muhammadiyah

Gorontalo, Indonesia

Email: nursida.arif@gmail.com

\begin{abstract}
This research aims to determine the risk of soil erosion qualitatively by integrating remote sensing with the geographic information system. Factors that contributed to the occurrence of erosion in the area of study were analyzed using the method of the variation of combined input data of the factors controlling erosion (soil, climate, topography, vegetation, and humans). The input data were quantitative data changed into qualitative data that were obtained from field data and extracted from remote sensing imagery, i.e. SPOT 5. A number of parameters were calculated using the RUSLE model equation. The model was validated by observing the qualitative erosion indicators in the field (pedestal, tree root exposure, armor layers, rill erosion, and gully erosion) by observing slope steepness in each sample area. The area of study was Serang watershed located in Kulon Progo Regency, Yogyakarta. It is one of the critically potential watersheds viewed from the landform and land use. The results of various combinations generated the highest of accuracy by $90.57 \%$ with extremely erosion dominating the area of study. The factors with the highest contribution to erosion in Serang Watershed were slope length and steepness (LS) and erodibility (K).
\end{abstract}

Copyright (C) 2017 GJGP-UNDIP

This open access article is distributed under $a$ Creative Commons Attribution (CC-BY-NC-SA) 4.0 International license.

How to cite (APA 6th Style):

Arif, N., Danoedoro, P., \& Hartono, H. (2017). Remote Sensing and GIS Approaches to a Qualitative Assessment of Soil Erosion Risk in Serang Watershed, Kulon Progo, Indonesia. Geoplanning: Journal of Geomatics and Planning, 4(2), 131-142. doi:10.14710/geoplanning.4.2.131-142

\section{INTRODUCTION}

Soil erosion is one of the indicators of land quality due to the destructive effect it has on land and the effect of reduced productivity of land (Morgan, 2009; Parveen \& Kumar, 2012). Erosion affects the sustainability of agricultural production on a global scale (Bouaziz, Leidig, \& Gloaguen, 2011). An assessment of erosion in an area is vital in order to evaluate land management and to provide a basis for land users and decision makers with regard to land conservation efforts and environmental monitoring. Numerous researches have been conducted, especially in the field of applied environment, including the research in erosion and landslides. These researches integrated remote sensing with the geographic information system which managed to generate more accurate and effective predictions (Asis \& Omasa, 2007; Liao et al., 2012; Pradhan, Lee, \& Buchroithner, 2010; Pradhan \& Saro, 2007).

Remote sensing and GIS can be used to generate information about the variables associated with the erosion calculation formula. There are many factors that contribute to erosion, namely rainfall, vegetation, topography, soil, and land use, all of which were used as the basis for assessing the erosion risk. This research relied on remote sensing data to obtain landscape information such as vegetation and land use while GIS was implemented to process, simulate scenarios, and visualize modeling results. The SPOT 5 imagery was used in this study because it offers a higher resolution of 2.5 to 5 meters in panchromatic mode and 10 meters in multispectral mode providing potential solutions in the study of natural resources. This is due to its capacity in covering vast areas such as area of study, as well as having channels that can decrease vegetation information through index $C$ as one of the model inputs. 
Most researches on soil erosion in the area of study were conducted using quantitative approaches to determine the amount of soil eroded in tons per hectare (Dibyosaputro et al., 2012; Santoso \& Senawi, 2012; Widarsih \& Senawi, 2012) and it is not common to assess erosion qualitatively. Basically, the qualitative approach employed in these researches was a combination of the quantitative approach. Factors controlling erosion were calculated using the RUSLE model equation and qualitatively divided into several classes. The output of the model was in the form of a qualitative map of the erosion risk without information about the amount of soil loss. A model is considered quantitative when the values are mathematically combined to provide an index at a certain scale (la Rosa \& Van Diepen, 2002). The numerical value of a variable may change at a certain period, unlike a qualitative assessment which tends to be more constant and unchanged (Bredeweg et al., 2009).

In this research, the field validation was qualitatively conducted by developing the formula for the assessment of the qualitative indicators of erosion. A high rate of erosion can be seen from the erosion indicators such as pedestal, armor layers, tree root exposure, rill erosion, and gully erosion (Stocking \& Murnaghan, 2000). To develop a quantitative model that can accurately represent the real condition in the field, it is necessary to conduct validation through detailed measurements for a long period of time requiring higher costs. In fact, the use of the erosion plot was rarely calibrated with the local condition and many used less realistic assumptions resulting in less reliable measurement results (Bergsma, 2008). This short coming makes qualitative methods reliable as a quick solution to predict erosion (Bouaziz, Leidig, \& Gloaguen, 2011; Desmet \& Govers, 1995). Ypsilantis (2011) stated that qualitative models of area method are effective and more affordable. They can be implemented in a larger area within a relatively short period of time, unlike quantitative methods that require intensive and more detailed monitoring of particular land conditions. This is in accordance with the conditions in Indonesia where the technical facilities and history of actual erosion measurement are minimal as shown in the study area. So that method is needed which can be the solution of the limitation with low cost and efficient but more accurate that is through qualitative based modeling by utilizing remote sensing image and geographic information system. It is expected that the method of fast assessment will be able to quickly locate which erosion-prone areas whose conservation should get priority.

\section{DATA AND METHODS}

\subsection{Study Area}

The research was undertaken in Serang Watershed which is situated between Progo Watershed and Bogowonto Watershed in Kulon Progo Regency, the Province of Yogyakarta Special Region. Geographically, it is located at $7^{\circ} 43^{\prime} 40^{\prime \prime} \mathrm{S}-7^{\circ} 55^{\prime} 30^{\prime \prime} \mathrm{S}$ and $110^{\circ} 03^{\prime} 49^{\prime \prime} \mathrm{E}-110^{\circ} 13^{\prime} 50^{\prime \prime} \mathrm{E}$. Administratively, it is located in Kulon Progo Regency, which includes several subdistricts, namely Wates, Sentolo, Temon Pengasih, Kokap, Girimulyo, and some area of Panjatan and Nanggulan subdistricts.

Based on the monthly rainfall data from 2004 to 2014 in 11 rainfall stations around Serang Watershed, the wet season occurred from November to April while the dry season occurred from May to October. Most stations in Serang Watershed fell into Category D, i.e. in a temperate climate. Most land in the area of study is utilized as mixed farms. In regard to the landform, the area of study is considered as an erosionprone area comprised of denudation-generated hills, which were formerly a volcano, and structural hills (Figure 1).

\subsection{Methods}

The variables employed to construct the model were the extraction of factors affecting erosion, namely climate, soil, vegetation, and humans. Field observation of the qualitative indicators of erosion was undertaken instead of quantitative calculations of the actual erosion for validation of the model. This research employed the same approach of qualitative methods conducted by Bouaziz, Leidig, \& Gloaguen (2011), namely trials on several combinations of factors controlling erosion to determine the most influential factor in the area of study. The input data set used in this modeling were factors influencing erosion, i.e. erosivity $(R)$, erodibility $(K)$, slope length and steepness (LS), vegetation coverage and management $(\mathrm{C})$, land management $(\mathrm{P})$. 


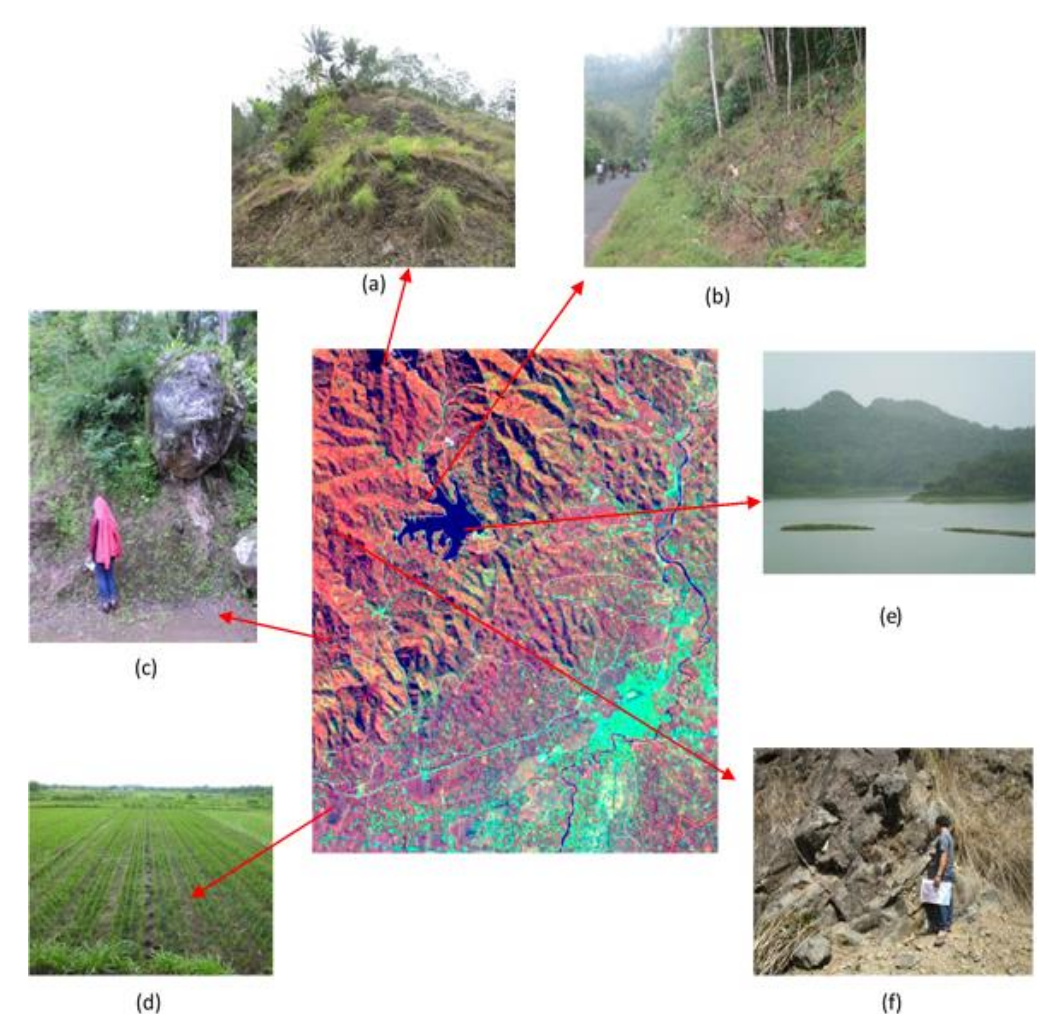

Figure 1. Appearance of Landforms (SPOT, 2014 and Analysis, 2016) (a) Structural rocky hills of andesite breccia (401494 mT, $9140214 \mathrm{mU}$ ), (b) and (c) Structural rocky hills of andesite (399202mT, $913234 \mathrm{mU}$ ), (d) Alluvial plain (401908 mT, 9,129279 mU), (e) Sermo reservoir, (f) Hills of the remains of a volcano (400833 mT, $9139855 \mathrm{mU}$ )

(1). Rainfall erosivity factor (R)

Erosivity index was calculated using 10 years of daily rainfall data from 13 rain stations around the research location, Utomo (1994) was calculated erosivity index using the equation (1) by Bols:

$R=6,12(R A I N)^{1,21} D_{A Y S^{-0,47}} M_{A X P^{0,53}}$

Where, RAIN = average annual rainfall $(\mathrm{cm})$, DAYS = total day of average rain per year (day), MAXP= maximum average rainfall in 24 hours per month within one year $(\mathrm{cm}), R_{m}=$ monthly erosivity index, $R_{y}$ $=$ annual erosivity index

(2). Soil erodibility factor (K)

$\mathrm{K}$ value was determined by the equation (2) used in RUSLE model developed by Renard et al. (1991) as follows:

$$
\mathrm{K}=7.594\left\{0.0017+0.049 \exp \left[-\frac{1}{2}\left(\frac{\log (D g)+1.675}{0.6986}\right)^{2}\right]\right\}
$$

Where, $\mathrm{K}=$ soil erodibility, $\mathrm{Dg}=$ Diameter of soil geometric particle $(\mathrm{mm})$

(3). Slope length and steepness factor (LS)

Length of slope was calculated using the equation (3) developed by Wischmeier et al. (1978) while steepness (S) was calculated using the LS equation (4-5) for USLE model developed by McCool et al., (1989)

$$
\mathrm{L}=\left(\frac{\lambda}{22.13}\right)^{\beta}
$$




$$
\begin{gathered}
\beta=\frac{\left(\frac{\sin \theta}{0.0896}\right) /\left[3 *(\sin \theta)^{0.8}+0.56\right]}{1+\left(\frac{\sin \theta}{0.0896}\right) /\left[3 *(\sin \theta)^{0.8}+0.56\right]} \\
S=\left\{\begin{array}{c}
10.8 \sin \theta+0.03 \theta \quad \theta<5^{\circ} \\
16.8 \sin \theta-0.5 \quad 5^{\circ} \leq \theta<10^{\circ} \\
21.9 \sin \theta-0.96 \quad \theta \geq 10^{\circ}
\end{array}\right.
\end{gathered}
$$

Where, $L=$ Slope length $S=$ Slope steepness; $\theta=$ Slope value of DEM; $\lambda=$ Slope horizontal length; $\beta=$ slope index, cell size $=$ size of grid cell

(4). Vegetation coverage and management factor (C), Xu, Xu, \& Meng (2012) explained that $C$ is defined as the ratio of soil loss from land cropped under spesific conditions to the corresponding loss from cleantilled, continous fallow. C value was calculated using Gutman \& Ignatov (1998) equation (6):

$C=1-\frac{N D V I-N D V I_{\min }}{N D V I_{\max }-N D V I_{\min }}$

\section{(5). Support practices factor $(P)$}

The support practice factor (P-factor) is the soil-loss ratio with a specific support practice to corresponding soil loss with up and down slope tillage. The erosion level due to land management and conservation activities $(P)$ varied, especially depending on slope steepness. Classification of $p$ values based on classification of slope developed by Shin (1999), show in Table 1.

Table 1.Classification of P-values (Modified from Shin (1999))

$\begin{array}{cc}\text { Slope }(\%) & \text { P-values } \\ \mathbf{0}-\mathbf{8} & 0.55 \\ \mathbf{8}-\mathbf{1 5} & 0.60 \\ \mathbf{1 5}-\mathbf{2 5} & 0.80 \\ \mathbf{2 5}-\mathbf{4 0} & 0.90 \\ \mathbf{4 0}> & 1.00\end{array}$

Calculation of erosion factors was performed on ArcGIS 10 platform and converted into raster format. The result of quantitative calculation was validated using qualitative approach by observing erosion indicators in the field. The erosion factors as the input data of the model were put in four combinations to examine the influential factors (Table 2). Additional data of the input layer were added to Combination 1 (C1), namely the map of solum depth and the map of organic matter. Both factors were considered affecting the ability of eroded soil. Organic matter do not only greatly affect the health of the soil but also soil properties, both the chemical properties and the physical properties, including the soil structure (Bot \& Benites, 2005). While the depth of the soil affects the soil-water-plant ecosystem so as to affect the quality and yield of plants (Jabro et al., 2010). Combination 2 (C2) was a combination of five erosion factors used in the RUSLE model equations, Combination 3 (C3) was comprised of only four factors without the factor of land management (P). As for Combination $4(\mathrm{C} 4)$, it only used three erosion factors, namely slope length and steepness factor (LS), erodibility (K), and the vegetation factor (C). Overall, the conceptual framework is illustrated in the form of a diagram shown in Figure 2.

\begin{tabular}{|c|c|c|c|c|}
\hline \multirow{2}{*}{ Factors Controlling Erosion } & \multicolumn{4}{|c|}{ Combinations } \\
\hline & $C_{1}$ & $C_{2}$ & $\mathrm{C}_{3}$ & $\mathrm{C}_{4}$ \\
\hline Topographic factor(LS) & $\checkmark$ & $\checkmark$ & $\checkmark$ & $\checkmark$ \\
\hline \multicolumn{5}{|l|}{ Soil properties } \\
\hline - $\quad$ erodibility (K) & $\checkmark$ & $\checkmark$ & $\checkmark$ & $\checkmark$ \\
\hline - Solum depth & $\checkmark$ & & & \\
\hline - $\quad$ Organic matter (OM) & $\checkmark$ & & & \\
\hline Rainfall erosivity ( R) & $\checkmark$ & $\checkmark$ & $\checkmark$ & \\
\hline Cover management factor (C) & $\checkmark$ & $\checkmark$ & $\checkmark$ & $\checkmark$ \\
\hline Practice factor $(\mathrm{P})$ & & $\checkmark$ & & \\
\hline
\end{tabular}

Table 2. Input parameters of three different combinations for the erosion risk assessment (Analysis, 2016) 


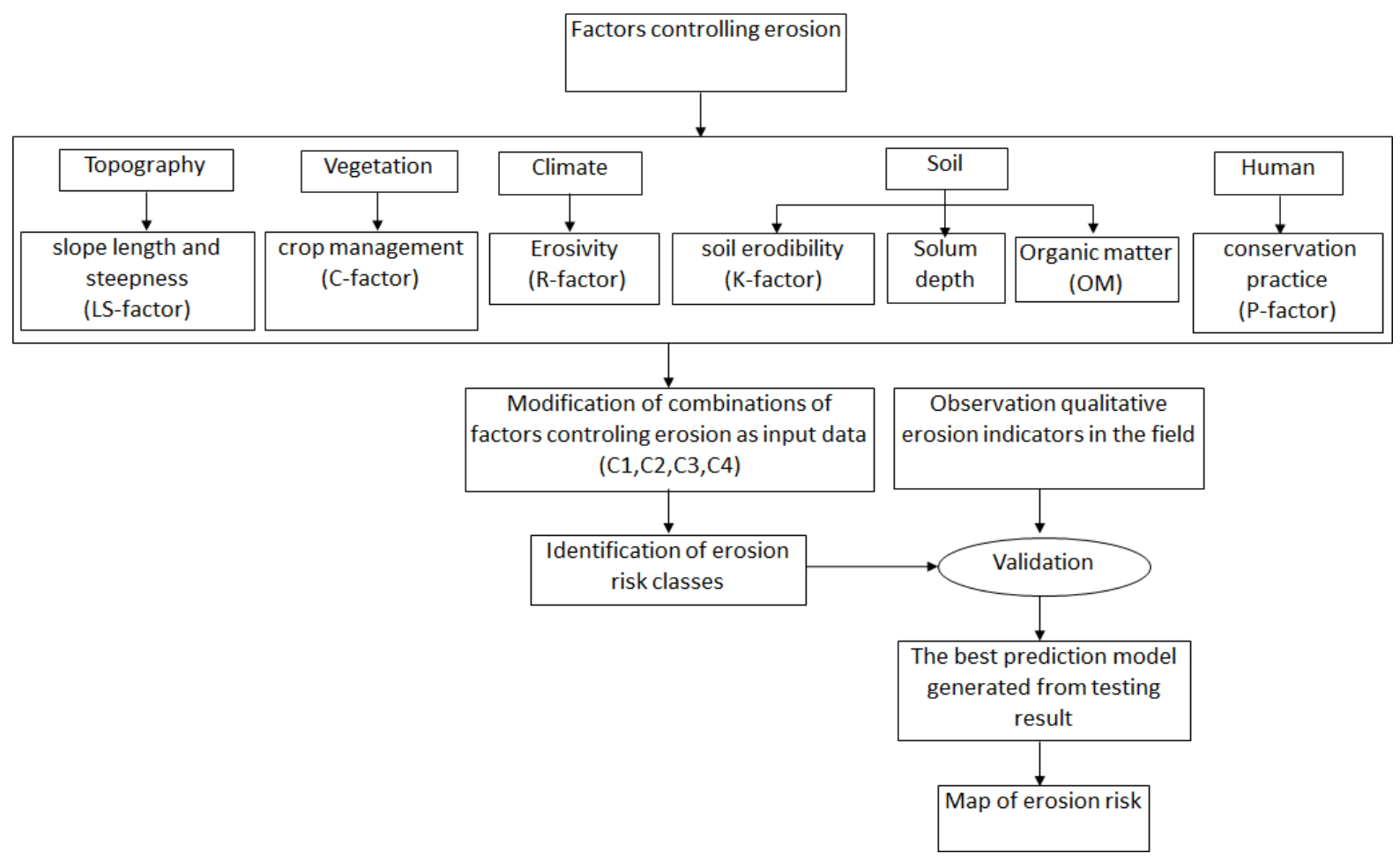

Figure 2. The Conceptual Framework of the Research

\section{RESULT AND DISCUSSION}

\subsection{Evaluation of Influential Erosion Factors}

R-factor value was made using spline interpolation method because the sample points were not spread evenly. This method has sufficient accuracy despite using a small amount of data. The spatial distribution of R-factor in Serang watershed ranged from the highest erosivity index value of 2,078.52 to the lowest $1,156.58$ (Figure 3a). The equation used to calculate $\mathrm{K}$-factor relied on soil texture data from the laboratory test results of soil samples. Soil texture is the most influential soil attributing to erodibility. Low erosion happened in soil with dominant element of sand (coarse texture) and soil with dominant fraction of loamy, while soil with main elements of dust and fine sand was easily eroded. The erodibility index in Serang watershed ranged from 0.46 to 0.09 (Figure $3 b$ ).

The spatial distribution of LS-factor ranged from the lowest value of 0.03 to the highest 427.50 (Figure 4a). The low slope steepness will have small contribution to LS value. If LS value is small, the erosion potential is equally small. The spatial distribution of C-factor show values between 0.01 and 1.43 (Figure $4 b)$. $C$ value approaches 0 for areas with denser vegetation (forest and mix plantation). Factor $C$ value gives contribution to interpretation and land use. Remote sensing through the SPOT 5 satellite could give solution to the extraction of factor $C$ value without performing measurement in the field. However, there was difference of factor $C$ value with previous researchers in the same area (Arsyad, 2010). Month of recording the images in use and climate difference, including rainfall, influence $C$ index value. The spatial distribution of P-factor with minimum index 0.55 in the flat slope and maximum index 1 in the steep slope (Figure 5a).

Soil organic matter and soil depth are additional data in $\mathrm{C}_{1}$. Soil organic matter in research area was obtained from laboratory test result on several samples while the soil depth of measurement result was obtained from the field. The sample value of soil organic matter and soil depth were then interpolated using kriging method to represent the maximum and minimum value of sample data. The spatial distribution of soil organic matter in Serang watershed showed values between 0.06 and 6.55 (Figure 5b). The spatial distribution of soil depth ranged from the lowest value of 19 to the highest 135 (Figure 6). 
After a comprehensive analysis of the entire combinations, the area of study is an erosion-prone area as indicated by the wide spread distribution of extremely to moderate erosion, whereas slight and very slight erosions occurred in a smaller percentage (Table 3, Figure 7). The model for $\mathrm{C}_{1}$ involved two soil attributes other than erodibility, namely organic matter and soil depth while the other combinations solitary used the factor of erodibility. However, $\mathrm{C}_{1}$ had a merely similar percentage of spatial distribution with the $\mathrm{C}_{3}$ and $\mathrm{C}_{4}$ for the slight erosion class (Figure $8 \mathrm{~b}$ ) and the severe erosion class for $\mathrm{C}_{4}$ (Figure $8 \mathrm{~d}$ ). This means that soil attributes other than erodibility did not significantly affect the erosion risk in the area of study.
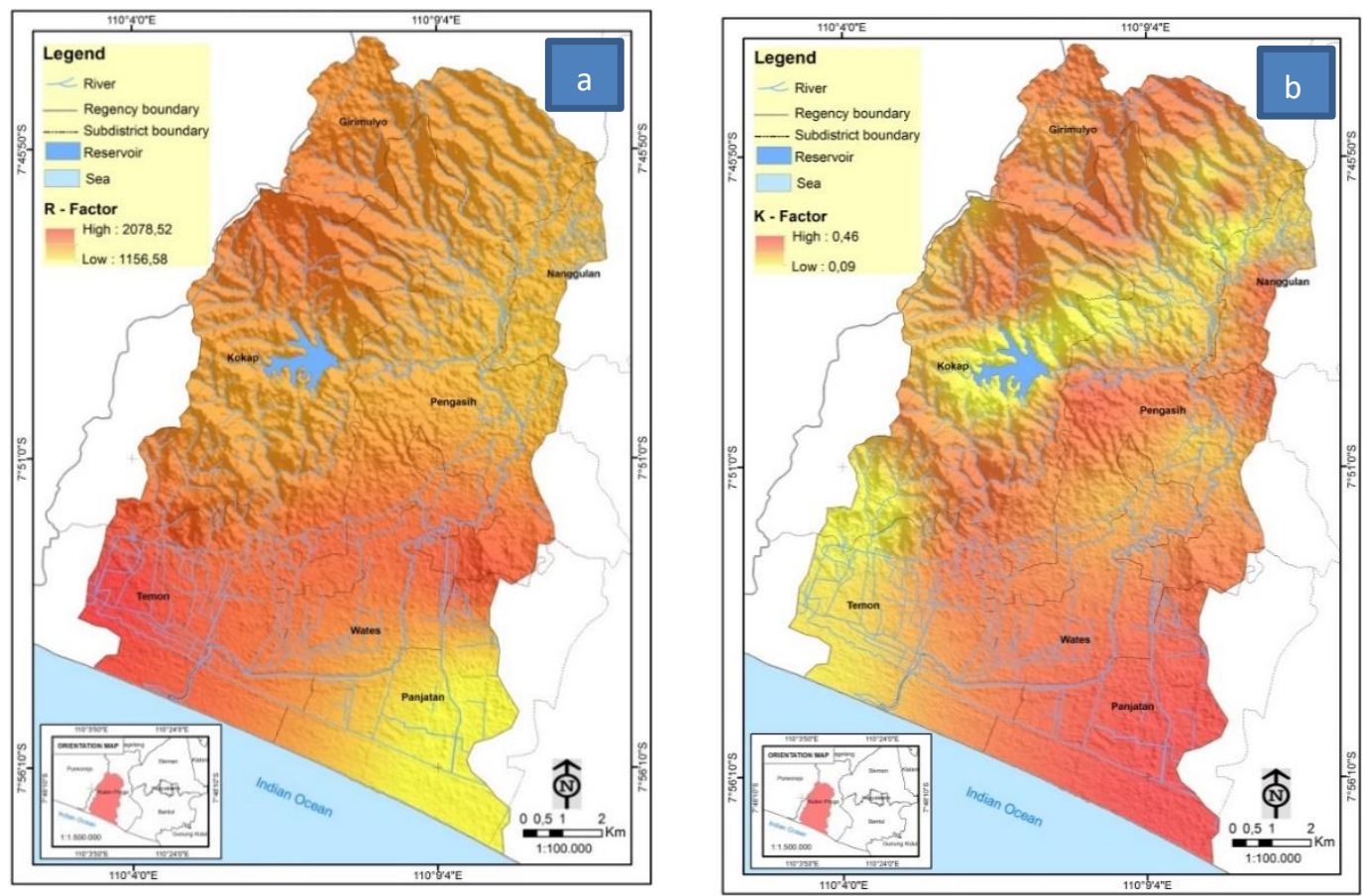

Figure 3. Spatial distribution: a.) rainfall erosivity factor (R) and b.) K factor
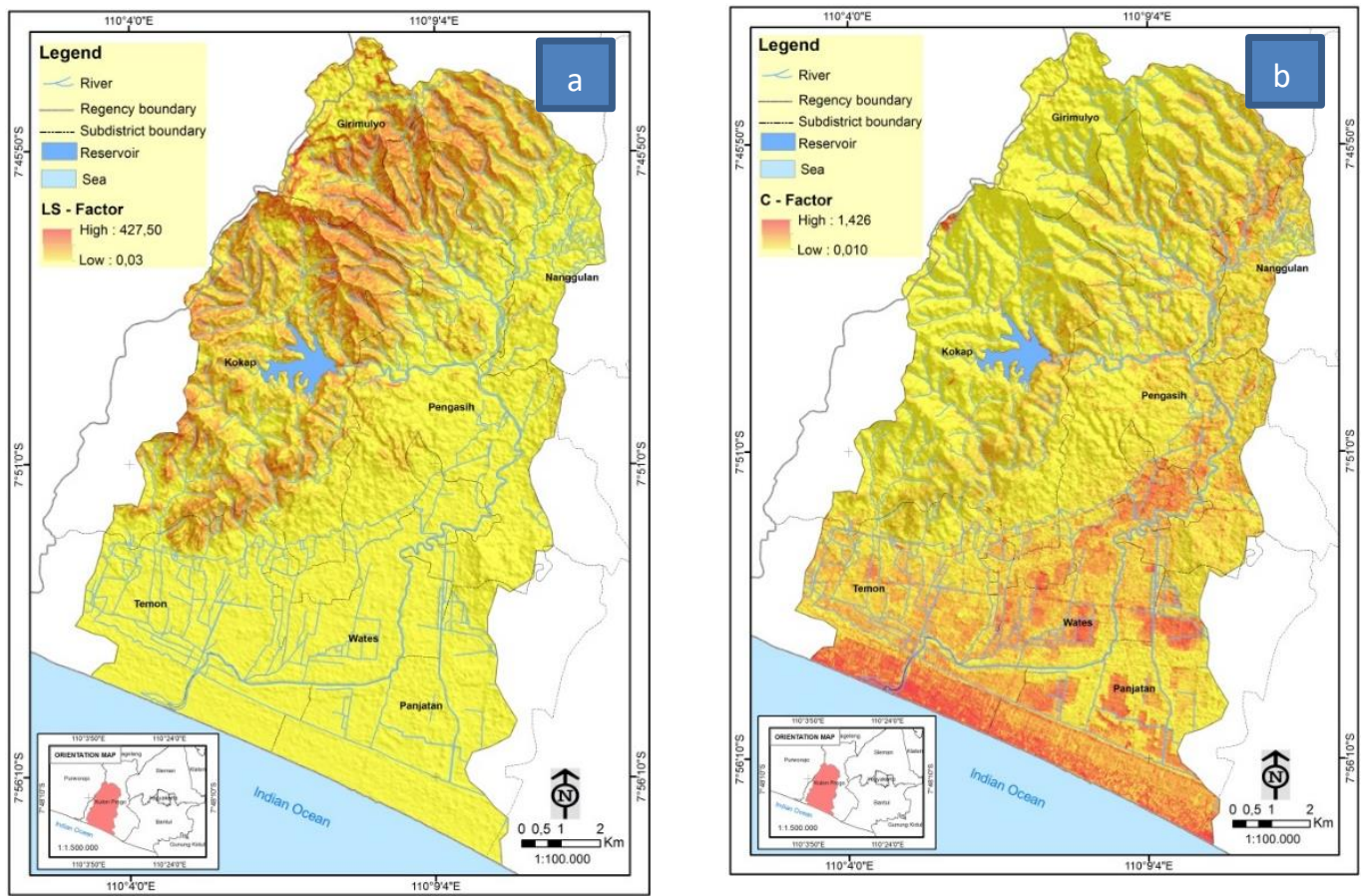

Figure 4. Spatial distribution: a.) slope length and steepness factor (LS) and b.) crop management factor (C) 

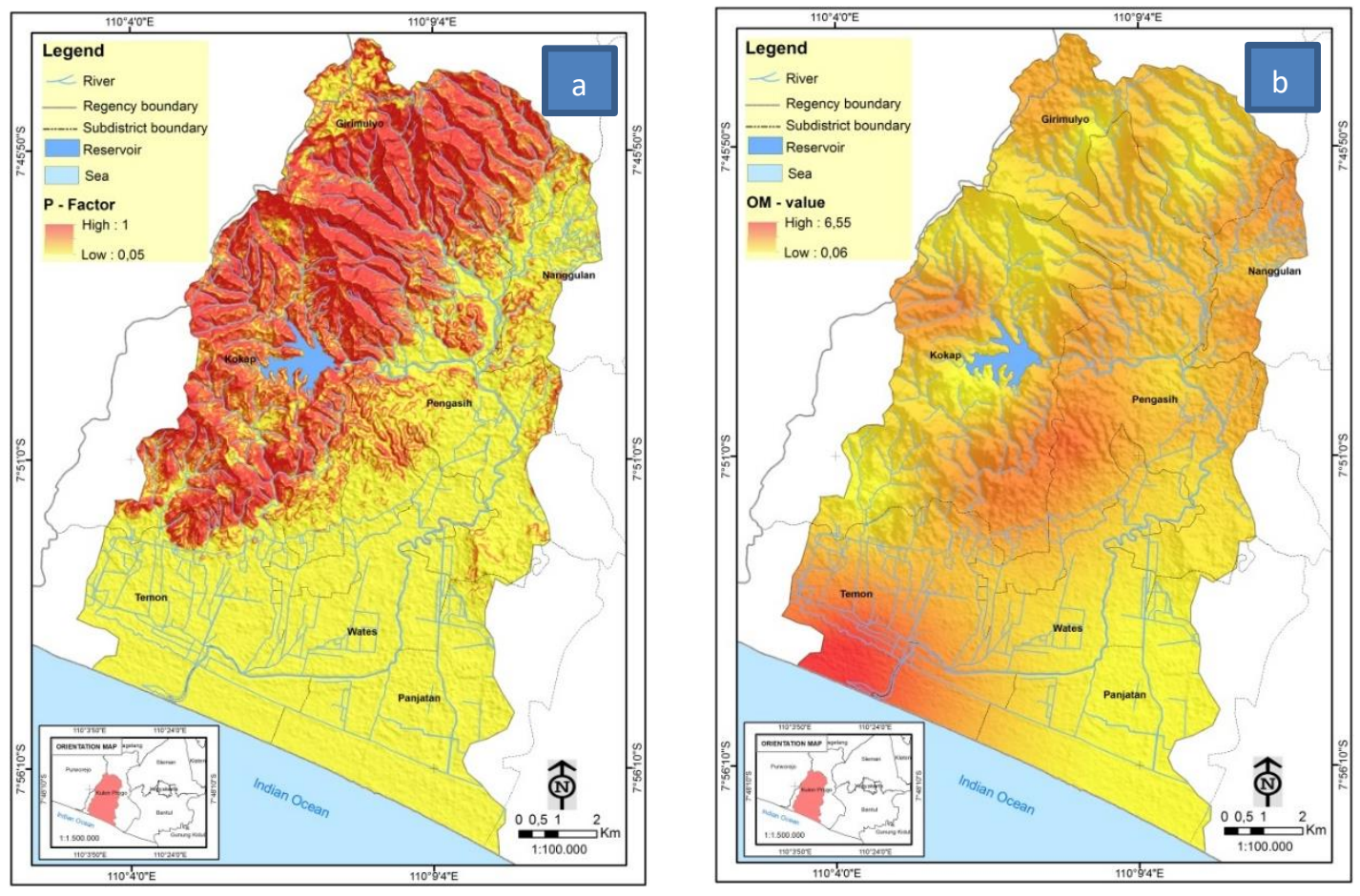

Figure 5. Spatial distribution: a.) support practice factor $(P)$ and b.) organic matter factor (OM)

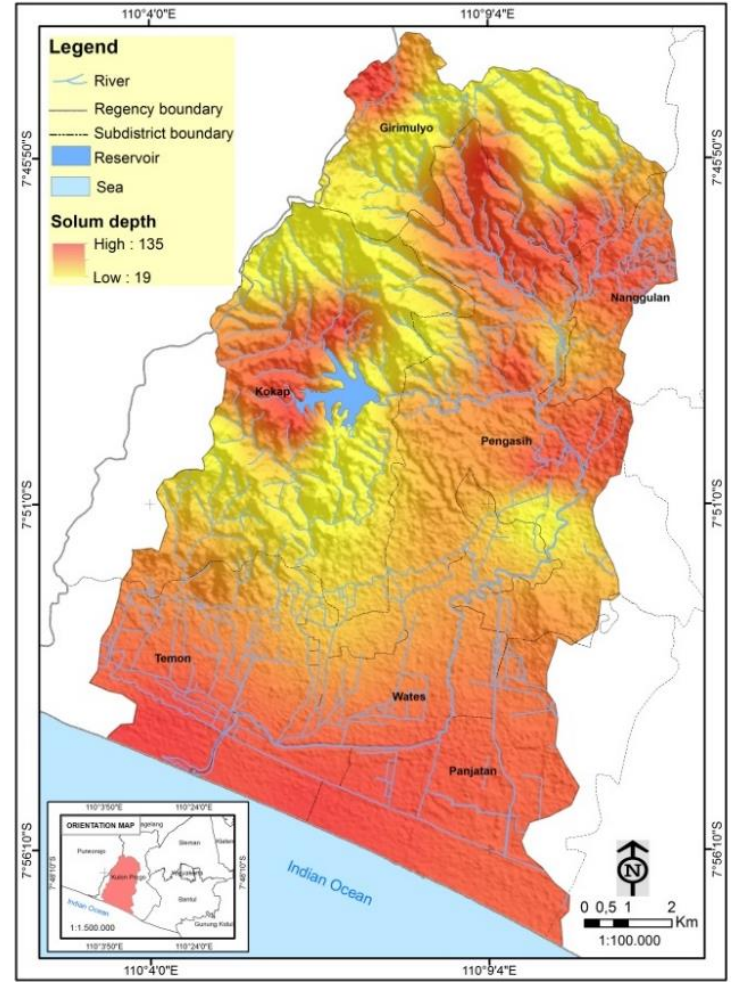

Figure 6. Spatial distribution of solum depth factor

The distribution of $C_{2}$ was almost the same as that of $C_{4}$ for the entire erosion classes (Figure 8). $C_{2}$ added the factors of erosivity $(R)$ and land management $(P)$ in addition to the factors used in $C_{4}$. It means that these two factors, namely factors $\mathrm{R}$ and $\mathrm{P}$, did not have a significant influence on the control of erosion in the area of study. The P factor map (Figure $5 a$ ) has the same distribution pattern as the LS factor map (Figure 4a) since both factors are derived from the same contour data, so the LS factor can replace the representation of factor $\mathrm{P} . \mathrm{C}_{3}$ and $\mathrm{C}_{4}$ had an almost equal distribution percentage for the very slight erosion class (Figure 8a). Both combinations used different factors, in which $\mathrm{C}_{4}$ did not use the factor of erosivity. In this case, it can be concluded that the factor of erosivity did not have a significant influence on the erosion in the area of study. 
Table 3. Distribution of the affected area by erosion classes (Analysis, 2016)

\begin{tabular}{lrrrr} 
& \multicolumn{4}{c}{ Model combination (\%) } \\
\hline Very slight & $\mathbf{C}_{\mathbf{1}}$ & $\mathbf{C}_{\mathbf{2}}$ & $\mathbf{C}_{\mathbf{3}}$ & $\mathbf{C}_{\mathbf{4}}$ \\
\hline Slight & 8.37 & 4.60 & 2.75 & 3.26 \\
\hline Moderate & 10.08 & 8.07 & 11.63 & 10.18 \\
\hline Severe & 20.07 & 30.54 & 26.12 & 32.16 \\
Extremely & 18.77 & 22.04 & 13.29 & 18.96 \\
\hline & 42.71 & 34.75 & 46.22 & 35.44
\end{tabular}

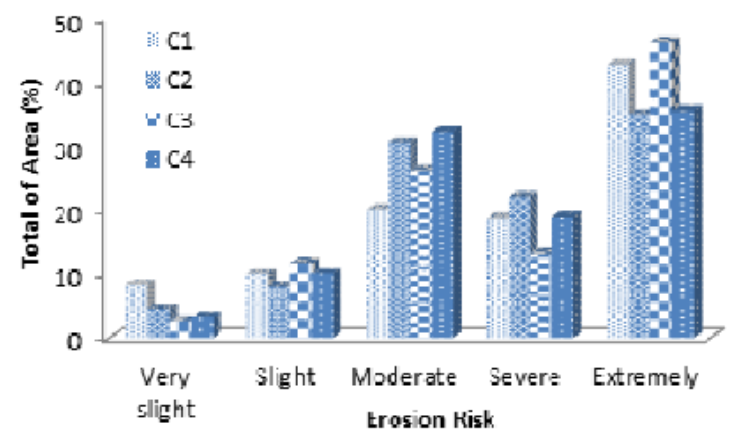

Figure 7. Distribution of erosion risk classes (Analysis, 2016)

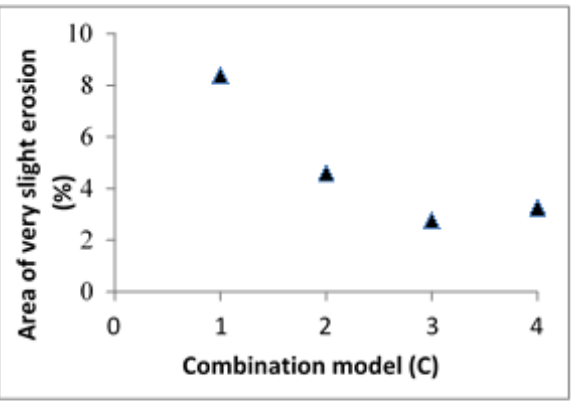

(a)

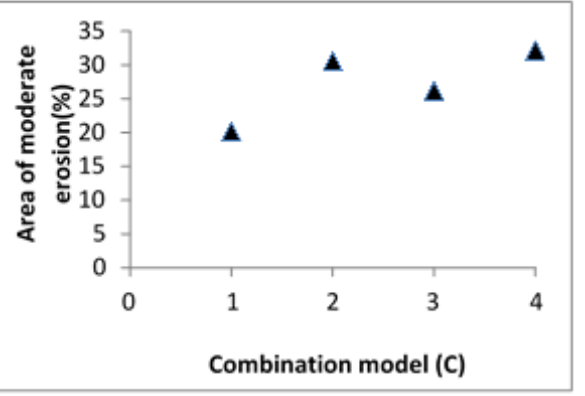

(c)

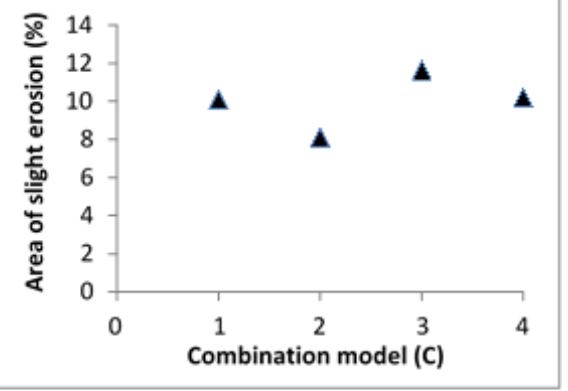

(b)

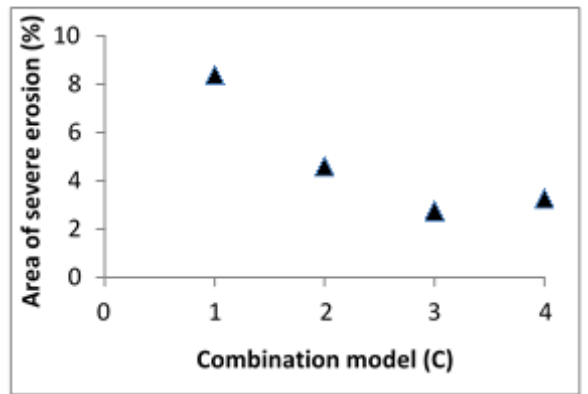

(d)

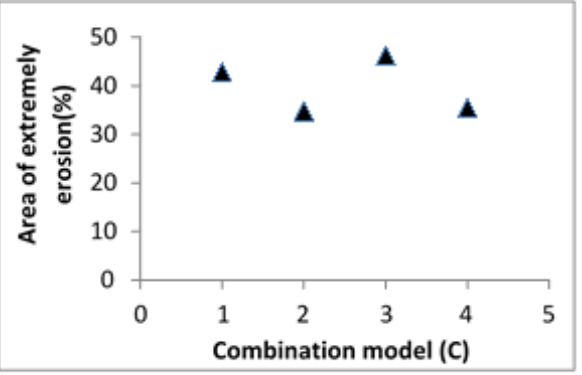

(e)

Figure 8. Distribution of the erosion risk model based on erosion risk classes (Analysis, 2016) (a). very slight, (b) slight, (c) moderate, (d) severe, (e) extremely 
Based on analysis results of various combinations (Figure 8) showed that the factors affecting erosion in the area of study were the slope length and steepness factor (LS) and erodibility (K). Kamaludin et al. (2013) showed the same thing that factors which potentially trigger erosion are LS and K. The factors of erodibility ( $R$ ) and vegetation cover (C) affect erosion if they take place simultaneously with the two influential factors (LS and K) as illustrated in Combination 2 (C2). Farhan, Zregat, \& Farhan (2013) drew the same conclusion that a combination of the factors of soil, slopes, and vegetation can describe the risk of erosion. The rainfall factor in significantly affected erosion in the area of study, except if high erosivity takes place steep slopes, the erosion risk will change into moderate up to extremely as in some areas of Girimulyo and Kokap subdistricts in the north (Figure 9).

The classification results based on the map of erosion risk distribution (Figure 9) reveal that the distribution of erosion in the research site was dominated by the following erosion classes, namely extremely erosion spreading across most of the area of Kokap Sub-district, Girimulyo Sub-district, and some of the area of Pengasih Sub-district; severe erosion spreading all over Panjatan Sub-district, Pengasih Subdistrict, Nanggulan Sub-district and some of the area of Kokap Sub-district; moderate erosion spreading across Pengasih Sub-district, some of the area in Wates Sub-district, Panjatan Sub-district and some of the area of Kokap Sub-district; as well as slight erosion and very slight erosion spreading all over Temon Subdistrict and Wates Sub-district.

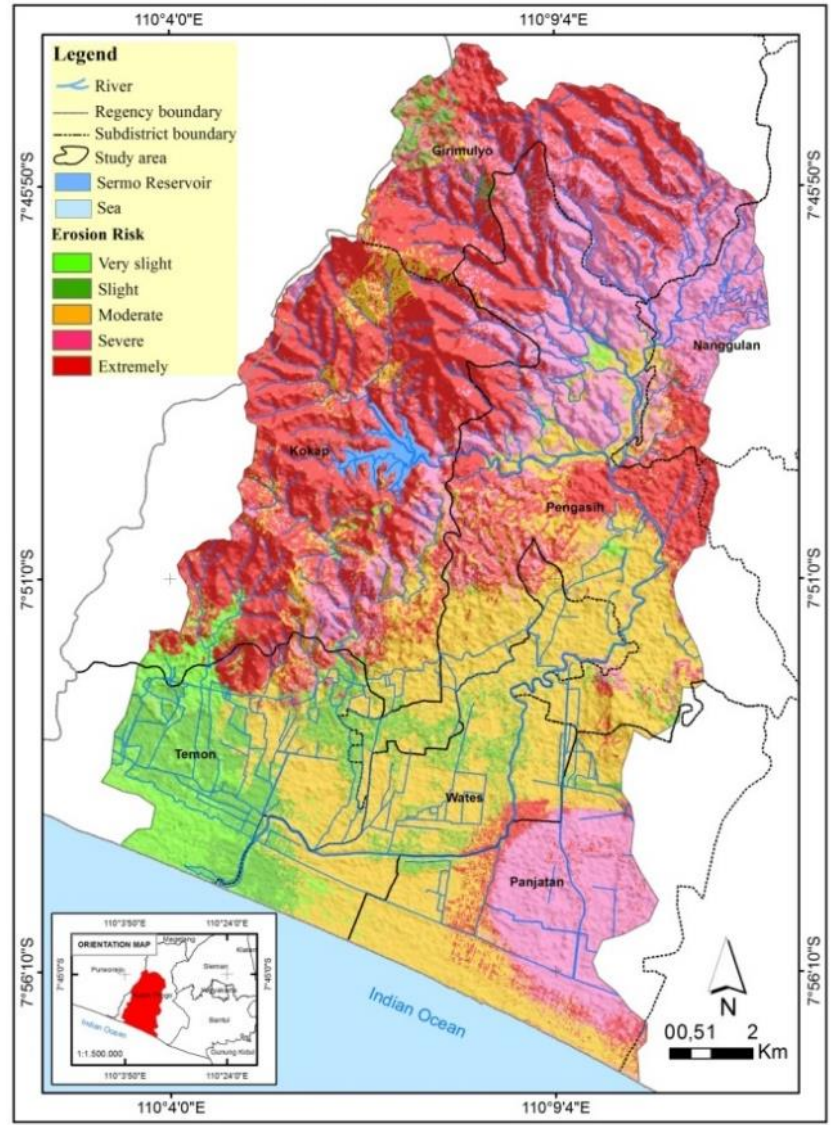

Figure 9. Spatial distribution of erosion risk $\left(C_{2}\right)$

\subsection{Validation}

Accuracy was ensured by testing 53 plots in the sample location in the erosion map generated using the four combinations using qualitative indicators in the field and the highest accuracy was generated by Combination 2 (Table 4) where the factors used were consisted of the five factors of erosion used in the model of erosion (R, K, LS, C, P). The lowest of accuracy, i.e. by $83.02 \%$, still can be used as a reference even though only three erosion factors were used, namely the slope length and steepness factor (LS), erodibility $(\mathrm{K})$, and vegetation $(\mathrm{C})$. 
Erosion classes were also determined by the slope steepness factor. Despite the indicators of erosion in the field, if they exist in a flat and sloping slope, the erosion will belong to the slight erosion class. Vrieling, Sterk, \& Vigiak (2006) argued that the slope factor and the occurrence of erosion significantly correlate; a very steep slope belongs to the severe erosion class. The more steepness slope is, the higher the number of particles that spreads to the lower slope so as to result in splash and rill erosion (Assouline \& Ben-Hur, 2006).

The erosion indicators showed the vulnerability of soil to erosion. Tree root exposure occurred in a place where plants or trees grow in an eroded area and, likewise, pedestals indicated a high erosion rate as they take place in soil that is easily eroded (high erodibility) by rainfall of high intensity (Stocking \& Murnaghan, 2000). Sheet erosion belonged to the slight and moderate categories because the runoff flow rate was not faster than that taking place in the rill and the gully, the resulting erosion did not lead to the formation of a rill and gully. Like the gully erosion, the rill erosion is one of the indicators of severe erosion, but the gully erosion cannot be removed through normal soil cultivation, like in the rill erosion. Therefore, the occurrence of gully erosion in an area indicates extremely erosion despite the absence of observation of other indicators such as pedestals (Figure 10) and tree root exposure (Figure 11).

Table 4. Comparison of the accuracy (analysis, 2016)

\begin{tabular}{lcc} 
& Overall accuracy (\%) & Index Kappa \\
\hline$C_{1}$ & 86.79 & 0.80 \\
$C_{2}$ & 90.57 & 0.86 \\
$C_{3}$ & 86.79 & 0.80 \\
$C_{4}$ & 83.02 & 0.73
\end{tabular}

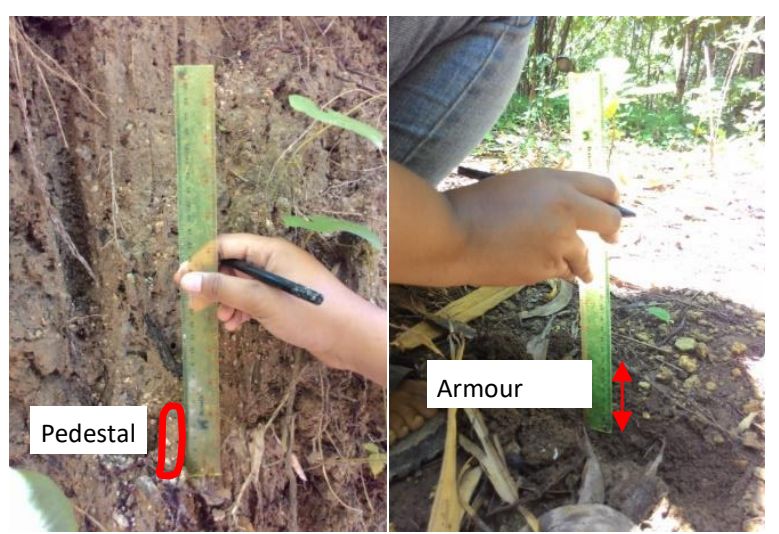

Figure 10. Appearance of Pedestals and Armour Layers Slight erosion risk (405113 mU, 9131329 mT)

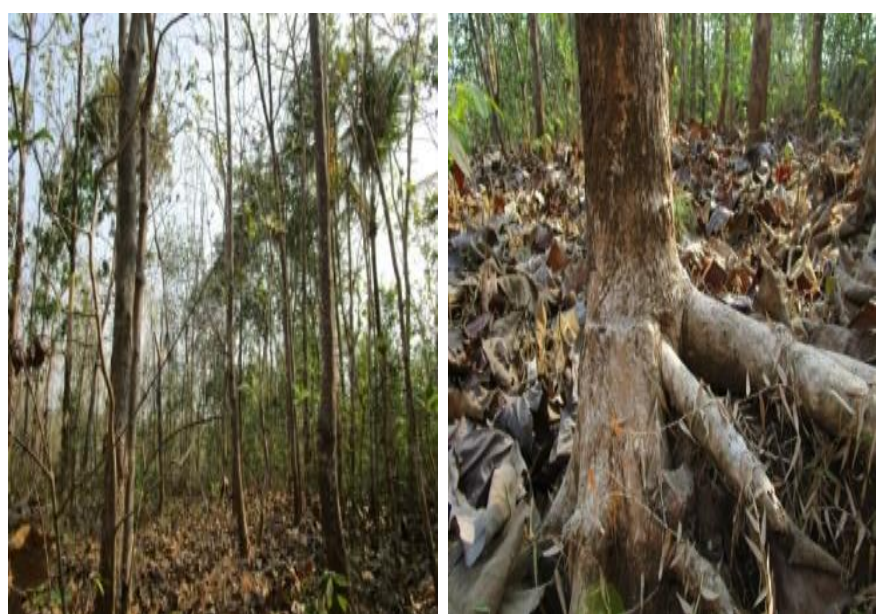

Figure 11. Tree root exposure, Location (410800 mU, 9140780 mT), Severe erosion risk (Analysis, 2016) 


\section{CONCLUSION}

Results of testing of the four combinations revealed that the area of Serang Watershed was dominated by the extremely erosion class with the most influential factors consisting of the slope length and steepness factor (LS) and erodibility (K). Results of the trial showed that the factor of soil management and cultivation (P) did not have a significant influence on the occurrence of erosion in the area of study because the $P$ value is derived from the same data to obtain the LS value of the contour data, so that the LS factor can replace the representation of factor $P$ as input data. Likewise, the addition of soil attributes in $C_{1}$, namely organic matter and soil depth, in this research did not improve the accuracy value.

\section{ACKNOWLEDGMENTS}

The authors would like to thank National Institute of Aeronautics and Space, Indonesia and Meteorological Climate and Geophysics Agency for providing the data. Fieldwork assistance was provided by Alfiatun Nur Khasana, Bagus Pamungkas, Lesan Purnomojati, Natassa Soeroso and Iwuk Lestari. The authors thank the financial support from Department of Higher Education of Indonesia, which has provided postgraduate scholarship in Universitas Gadjah Mada, Yogyakarta.

\section{REFERENCES}

Arsyad, S. (2010). Konservasi Tanah \& Air. Institut Pertanian Bogor

Asis, A. M. de, \& Omasa, K. (2007). Estimation of vegetation parameter for modeling soil erosion using linear Spectral Mixture Analysis of Landsat ETM data. ISPRS Journal of Photogrammetry and Remote Sensing, 62(4), 309-324. [Crossref]

Assouline, S., \& Ben-Hur, M. (2006). Effects of rainfall intensity and slope gradient on the dynamics of interrill erosion during soil surface sealing. Catena, 66(3), 211-220. [Crossref]

Bergsma, E. (2008). Erosion by Rain: its subprocesses and diagnostic micro-topographic features. Institute for Geo-Information Science and Earth Observation (ITC), Enschede, The Netherlands.

Bot, A., \& Benites, J. (2005). The importance of soil organic matter: key to drought-resistant soil and sustained food production. Food \& Agriculture Org.

Bouaziz, M., Leidig, M., \& Gloaguen, R. (2011). Optimal parameter selection for qualitative regional erosion risk monitoring: A remote sensing study of SE Ethiopia. Geoscience Frontiers, 2(2), 237-245. [Crossref]

Bredeweg, B., Linnebank, F., Bouwer, A., \& Liem, J. (2009). Garp3-Workbench for qualitative modelling and simulation. Ecological Informatics, 4(5), 263-281. [Crossref]

Desmet, P. J. J., \& Govers, G. (1995). GIS-based simulation of erosion and deposition patterns in an agricultural landscape: a comparison of model results with soil map information. Catena, 25(1-4), 389-401. [Crossref]

Dibyosaputro, H. S., et. al. (2012). Pola Persebaran Keruangan Erosi Permukaan sebagai Respon Lahan Terhadap Hujan di Daerah Aliran Sungai Secang, Kabupaten Kulonprogo, Daerah Istimewa Yogyakarta Indonesia. Universitas Gadjah Mada.

Farhan, Y., Zregat, D., \& Farhan, I. (2013). Spatial estimation of soil erosion risk using RUSLE approach, RS, and GIS techniques: a case study of Kufranja Watershed, Northern Jordan. Journal of Water Resource and Protection, 5(12), 1247. [Crossref]

Gutman, G., \& Ignatov, A. (1998). The derivation of the green vegetation fraction from NOAA/AVHRR data for use in numerical weather prediction models. International Journal of Remote Sensing, 19(8), 15331543. [Crossref]

Jabro, J. D., Stevens, W. B., Iversen, W. M., \& Evans, R. G. (2010). Tillage depth effects on soil physical properties, sugarbeet yield, and sugarbeet quality. Communications in Soil Science and Plant Analysis, 41(7), 908-916. [Crossref]

Kamaludin, H., et. al. (2013). Integration of remote sensing, RUSLE and GIS to model potential soil loss and sediment yield (SY). Hydrology and Earth System Sciences Discussions, 10(4), 4567-4596. [Crossref]

la Rosa, D., \& Van Diepen, C. (2002). Qualitative and quantitative land evaluation. In 1.5. Land use and land cover, Encyclopedia of Life Support System (EOLSS. UNESCO)(Verheye W, ed.), Eolss Publ, Oxford, UK.

Liao, Z., et. al. (2012). Environmental emergency decision support system based on Artificial Neural Network. Safety Science, 50(1), 150-163. [Crossref] 
McCool, D. K., et. al. (1989). Revised slope length factor for the Universal Soil Loss Equation. Transactions of the ASAE, 32(5), 1571-1576. [Crossref]

Morgan, R. P. C. (2009). Soil erosion and conservation. John Wiley \& Sons.

Parveen, R., \& Kumar, U. (2012). Integrated approach of universal soil loss equation (USLE) and geographical information system (GIS) for soil loss risk assessment in Upper South Koel Basin, Jharkhand. Journal of Geographic Information System, 4(6), 588. [Crossref]

Pradhan, B., Lee, S., \& Buchroithner, M. F. (2010). A GIS-based back-propagation neural network model and its cross-application and validation for landslide susceptibility analyses. Computers, Environment and Urban Systems, 34(3), 216-235. [Crossref]

Pradhan, B., \& Saro, L. (2007). Utilization of optical remote sensing data and GIS tools for regional landslide hazard analysis using an artificial neural network model. Earth Science Frontiers, 14(6), 143-151. [Crossref]

Renard, K. G., et. al. (1991). RUSLE: Revised universal soil loss equation. Journal of Soil and Water Conservation, 46(1), 30-33.

Santoso, H. B., \& Senawi, M. P. (2012). Arahan Penggunaan Lahan Optimal Berdasarkan Aspek Biofisik dan Kebutuhan Minimal Lahan Pertanian untuk Pengendalian Erosi di Das Serang. Universitas Gadjah Mada.

Shin, G. J. (1999). The analysis of soil erosion analysis in watershed using GIS. Ph. D. Dissertation, Department of Civil Engineering, Gang-won National University.

Stocking, M., \& Murnaghan, N. (2000). Land degradation--guidelines for field assessment. Overseas Development Group, University of East Anglia, Norwich, UK, 120.

Utomo, W. H. (1994). Erosi dan Konservasi Tanah. Penerbit IKIP Malang

Vrieling, A., Sterk, G., \& Vigiak, O. (2006). Spatial evaluation of soil erosion risk in the West Usambara Mountains, Tanzania. Land Degradation \& Development, 17(3), 301-319. [Crossref]

Widarsih, S., \& Senawi, M. P. (2012). Pendugaan Erosi, Kemampuan dan Kekritisan Lahan untuk Rehabilitasi Sub DAS Tinalah, DAS Progo. Universitas Gadjah Mada.

Wischmeier, W. H., Smith, D. D., \& others. (1978). Predicting rainfall erosion losses-a guide to conservation planning. Predicting Rainfall Erosion Losses-a Guide to Conservation Planning.

Xu, L., Xu, X., \& Meng, X. (2012). Risk assessment of soil erosion in different rainfall scenarios by RUSLE model coupled with Information Diffusion Model: A case study of Bohai Rim, China. Catena, 100, 7482. [Crossref]

Ypsilantis, B. (2011). Upland Soil Erosion Monitoring and Assessment. Bureau of Land Management, National Operations Center. 